London but also the social changes in the whole country and their impact on the medical and nursing professions generally.

The London Hospital has certainly not lacked powerful and picturesque personalities on its staff but the two people about whom the reader learns most in this book were not medically qualifiedMiss Lückes the matron whose reforms were so much needed but who met so much opposition and Sydney Holland, perhaps the most active and wellknown hospital chairman of all time. His efforts to raise large sums of money for the hospital were extraordinary. Our financial problems loom large enough in state-aided hospitals nowadays but how much greater were the difficulties for those who ran hospitals on an entirely voluntary basis. It is difficult for younger doctors to understand how their elders can ever have contemplated withstanding a system which would introduce subsidies and banish public begging.

Only "Londoners" will fully appreciate the last chapters with their descriptions of many events of only local interest and of characters little known outside Whitechapel. It may seem curious to laymen that a hospital, an institution which often spells tragedy to so many people, can, like a college or a school, arouse feelings of loyalty and devotion to the doctors who have worked there. Dr. ClarkKennedy has no doubts about the value of a pride in history and of a great tradition; he has certainly given "Londoners" plenty of material for a justifiable pride in their hospital.

\section{The Genetics of Bacteria and their Viruses-Studies in Basic Genetics and Molecular Biology}

Edited by William Hayes. Pp. $740+$ xxv. Oxford: Blackwell Scientific Publications. 1964. 84s.

The study of microbial genetics and molecular biology is interesting, but difficult to master. This substantial volume of 740 pages fills the need for a comprehensive account of genetics of bacteria and their viruses. It is an advanced book and covers the major developments in the field which have been made during the past few years and their interpretation at the molecular level. It will be of great help to biochemists, bacteriologists and virologists as well as to physicists, who are engaged in post-graduate studies and research in this field, as well as being a valuable reference book.

The introductory chapter deals with the preliminary and basic facts of genetics, such as anatomy of inheritance Mendel's Laws of Inheritance and the elements of genetic analysis, which could be read with interest and profit by medical students and young doctors. The author then takes the reader through the integration of genetics and biochemistry, and bacterial mutation, and discusses in greater detail the physiochemical mechanisms of heredity, the chemistry of D.N.A. and D.N.A. as a genetic material. Finally, there is a section on the physiology and genetics of bacteria and bacteriophage. Each chapter begins with a concise but general historical introduction and clear definitions of the nomenchture used. The chapters dealing with mutation, chromosome morphology in bacteria and bacteriophage, and their methods of study, the nature $\overline{\text { of }}$ chromatin bodies, and the study of D.N.A. uptaye are particularly informative.

As an experienced teacher in the subject, tre author tries to make the difficult facts clear interesting diagrams and illustrations. A tremendoess amount of information has been assembled, generafy clear and of a high overall standard. The book ois excellently produced, easy to handle and prints are clear. There are twenty-six valuable photographic plates. More than eight hundred references at the end of the book cover most publications in this fiefel in recent years.

Data Acquisition and Processing in Biology and Medicine Volume 2 (Proceedings of the Rochest Conference)

Edited by K. Enslein. Pp. 367. Oxford, Londôn and New York and Paris: Pergamon Press. 1964. 80 s.

It seems certain that the present decade will sed the electronic computer play an increasingly impofant role in medicine, spreading from the province of the research worker and statistician to that of the general clinician. Just how far development hamd advanced by 1962 is unfolded in the pages of this fascinating volume, a collection of papers delivered at a conference held in Rochester, N.Y. to discus automatic data-handling methods in biology gand medicine. Anyone who doubts that we are moळing into an age of computer medicine would be $\$$. advised to ignore the rather forbidding title $\bar{q}$ ind browse among the twenty-six articles which itge book comprises. Those of most general interest a to be found in the large section on diagnost procedures and treatment, which demonstrates ho a computer can act as expert "consultant" to the doctor with a diagnostic problem-for example, the assessment of thyroid function from clinical and laboratory data, in the interpretation of pædiatr? electrocardiograms, or in the psychiatric analysis of speech disturbances.

Elsewhere, it is shown how computer technique can simply such twentieth-century complexities as the rapid retrieval of information from the medical literature (or from hospital records) and the monitoring of critically-ill hospital patients, while a number of other papers deals with more specialised applicat tions in the fields of neurophysiology, microbiolog and biochemistry. Much of the book is too technica for the general reader, but its value will be correspondingly enhanced for those wishing actually to avail themselves of this new and exciting toof of medical science. 